\title{
Is There an Information Literacy Skills Gap to Be Bridged? An Examination of Faculty Perceptions and Activities Relating to Information Literacy in the United States and England
}

\section{Jacqui Weetman DaCosta}

Surveys of faculty were conducted at two higher education institutions in England and the United States to ascertain their perceptions of information literacy. Faculty were also asked about the extent to which they incorporated information literacy skills into their courses. Similarities were found across the two institutions both in the importance that faculty attached to information skills and what they actually did to incorporate the skills within curricula. The results reflect an information literacy skills gap between what faculty (and librarians) want for their students and the practical reality. Librarians and faculty should work collaboratively together to bridge this gap.

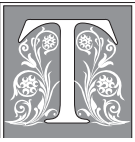

his paper originally grew out of research conducted for a master's program in Educational Management, which was studied in the United Kingdom. The intention was to ascertain faculty views on information literacy, rather than just make assumptions on their knowledge of the skills and interest in the concept. It was also deemed highly relevant, if information literacy was to be promoted throughout the institution, for data on current faculty activity in this area to be gathered and evaluated. When the researcher moved from England to the United States, it was obvious that conducting a similar research exercise would be beneficial in another institution, and it is hoped that the findings from both might help enlighten future librarian/ faculty collaborative work.

\section{Literature Review}

The opinions of faculty regarding information literacy and their levels of involvement in the teaching of it have interested librarians for many years. Studies have been published across the world outlining research on faculty perceptions of information literacy within specific institutions and disciplines. Much of this research has confirmed what librarians have suspected all along: Faculty generally agree on the importance of information literacy but 
need more of a push to truly embrace it within the curriculum.

Hardesty ${ }^{1}$ started the ball rolling with his seminal work on what faculty thought about the educational role of the academic librarian. In the 1970s and 1980s, he and his fellow academic librarians discovered that the best way to improve student use of the library was to work with faculty, but this was found to be a greater challenge than expected. Many have used Hardesty's work as a baseline and benchmark for subsequent reviews of faculty/librarian relationships. Reviewing the literature fifteen years later, McGuinness concluded that much "of our knowledge of faculty attitudes towards, and perceptions of, information literacy development, have been shaped primarily by second-hand accounts of their behavior." ${ }^{2}$

Studies conducted within the last decade have made some progress at providing first-hand faculty accounts of their information literacy perceptions and activities. However, these have tended to focus on specific subject disciplines. Singh ${ }^{3}$ surveyed faculty teaching in Journalism and Mass Communication programs. She asked faculty to rate their students' information literacy skills against the ACRL Standards and investigated the extent to which information literacy was taught or assessed within these programs. Her results showed that faculty require students to do library research as part of their courses; they are aware that students are not as information literate as they could be; and they know that library instruction can improve students' research skills. Boon, Johnston, and Webber ${ }^{4}$ undertook a three-year research project in the United Kingdom that looked at faculty conceptions of information literacy in four disciplines: English, Marketing, Chemistry, and Civil Engineering. They found that information literacy competencies were highly valued by faculty in these disciplines. In their report on their work with English faculty, where they applied a phenomenographic research methodology, they noted that faculty placed a greater emphasis on students' ability to access and retrieve information and less on the ability to recognize the information need. This is contrary to the librarian-generated standards and frameworks and raises an interesting question for further developmental work in this area.

Gullikson's ${ }^{5}$ research was not limited to a specific discipline but focused on five Canadian universities. She developed an extensive survey to ascertain which outcomes from the ACRL Standards were most relevant to faculty and at what stage they expected students to use the skills. Her findings were that faculty saw the importance of information literacy skills; but there was no overall agreement on when students should acquire the skills, as this can vary between disciplines.

Little has been written on information literacy outside of library literature; and, where articles were found in mainstream educational journals, most were written by library and information professionals. Despite the fact that Australian universities have been proactive in the development of information literacy, Christine Bruce commented in 2001: "It has been evident that little of the literature is appearing in mainstream higher education journals or discipline-based journals, suggesting that the transformation of the information literacy agenda from a library-centered issue to a mainstream educational issue is only beginning. " ${ }^{\prime 6}$ Some writers believe that the reason for information literacy not being part of the mainstream higher educational agenda is that many faculty believe that students just acquire these skills, rather than needing to be taught them. ${ }^{7}$

Bruce's extensive work in Australia went so far as to explore definitions of information literacy with faculty using, as one of the suggested models, her own "seven faces of information literacy" achieve a shared understanding. MacDonald, Rathemacher, and Burkhardt ${ }^{9}$ also achieved this, at the University of Rhode Island, and Zhang ${ }^{10}$ perceives that it is the only way to progress curriculum development in the sphere of information literacy. 
Bruce, Chesterton, and Grimison ${ }^{11}$ were able to develop an institutional collective consciousness regarding information literacy; and this was achieved through management commitment, staff development, and attention to national standards. A common and strong impediment to developing this institutional collective consciousness can often be the perception of many faculty that computer literacy equals information literacy. ${ }^{12}$

Many writers suggest ways in which librarians can win the trust of faculty and demonstrate to them that their professional skills are not just limited to showing students how to "point and click" on a database. Shen and Gresham ${ }^{13}$ offer advice on becoming more involved in faculty activities, being more service oriented as well as displaying proficiency with information technology. Doskatsch ${ }^{14}$ goes a step further by recommending that librarians are involved in developing learning and teaching strategies while acquainting themselves with the institution's mission and strategic plan.

It is often said and felt that students would better appreciate the importance of information skills training if it was formally assessed and, ideally, part of a creditbearing course. Johnston and Webber proffer that: "Once a subject has achieved credit-bearing status, students are likely simply to accept that it has some weight."15 Fiegen, Cherry, and Watson ${ }^{16}$ worked with faculty to produce an assessment-planning instrument that could be easily selfadministered to identify and incorporate information skills into courses.

The literature shows that the subject of information literacy is of great importance to library and information professionals around the world but does not illustrate a wider acceptance and adoption within higher education in general. It is questioned whether this low level of adoption is due to a lack of understanding on the part of faculty and/or an inability to teach the required skills. Most of the researchers feel that collaboration between librarians and faculty is needed to ensure that infor- mation literacy is integrated into subject curricula and, where possible, formally assessed. It is believed that librarians should be involved with curriculum development to incorporate information literacy learning outcomes.

\section{Research Conducted in England}

In March and April 2004, research was undertaken at a specific British higher education institution, De Montfort University (DMU), which was then a three-campus university based in Leicester and Bedford. ${ }^{17}$ It had approximately 19,000 students and 1,600 academic teaching staff and was divided into 6 areas, known as faculties:

- Art and Design

- Business and Law

- Computing Sciences and Engineering

- Education and Contemporary Studies

- Health and Life Sciences

- Humanities

The research was undertaken to ascertain faculty perceptions of information literacy and to what extent the library's bibliographic instruction program was meeting the needs of courses.

Questionnaires were sent out to 478 module leaders, within the final year of undergraduate courses, across all faculties and campuses. (At DMU, a course is normally a three-year undergraduate program comprising 360 credits. The course is made up of subject modules to which are attached 15,30 , or 60 credits. A module leader is the member of faculty responsible for the coordination of the module.) A total of 98 questionnaires were completed, giving a 21 percent response rate. This study showed that faculty were enthusiastic about information literacy and believed that students should acquire such skills; but they also felt that there were low levels of activity in terms of information literacy being incorporated within faculty teaching. The research confirmed librarians' suspicions that faculty expected information literacy skills to be largely acquired through what Claire McGuinness ${ }^{18}$ describes as "osmosis." Interviews that she conducted with 
faculty in Ireland led her to conclude that "[t]here was a tacit assumption among faculty that students would somehow absorb and develop the requisite knowledge and skills through the very process of preparing a piece of written coursework, and by applying the advice meted out by their supervisors."19

Two similar, but shorter, surveys were subsequently conducted at DMU (Leicester campus). Unlike the original study, which utilized as its research population all faculty teaching final-year (in other words, senior-level) courses, the subsequent surveys targeted specific subject disciplines:

- Architecture faculty (May 2005)

- Art and Design faculty (January 2006)

The survey that was used on both of these occasions was reduced in size by half. (The original questionnaire had included questions relating to preferred teaching methods and to the types of resources that faculty felt were necessary for their students to use for research.) Another difference was that the first survey asked faculty to what extent they agreed with the following American Library Association (ALA) statement: "An information literate student is one who can recognize when information is needed and have the ability to locate, evaluate and use effectively the needed information." ${ }^{20}$ In March 2004, this definition of information literacy was used because there was no agreed British equivalent. However, in December 2004, the Chartered Institute of Library and Information Professionals (CILIP) published a British definition, so this was included in the subsequent questionnaires. The CILIP defini- tion of information literacy is as follows: "Information literacy is knowing when and why you need information, where to find it, and how to evaluate, use and communicate it in an ethical manner." ${ }^{21}$

In the original research, faculty were asked to comment on seven skills taken from the Society of College, National and University Libraries (SCONUL) "Seven Pillars of Wisdom" model ${ }^{22}$ and identify, for each of the skills, which ones they thought were:

A. important for students to have acquired by the end of their course;

B. specifically taught on final-year modules;

C. developed through student-centered learning on final-year modules; and

D. assessed on final-year modules.

When the original results were analyzed, it was felt that there had been an omission by not asking faculty whether they thought that students had acquired these skills by the end of their degree program, so this was added as column E) on the subsequent questionnaires.

With both of the follow-up surveys, the distribution method mirrored that of the original research. Paper questionnaires were individually addressed and sent through the internal mail to faculty in the Architecture department (May 2005) and to Art and Design (January 2006). The response rates are shown in table 1 , with a comparison to the response rate from the 2004 survey.

Where the sample sizes were smaller, it was easier to follow up responses. (On all three occasions, two e-mail reminders were subsequently sent at two-week intervals.) It probably also helped that the

\begin{tabular}{|l|c|c|c|}
\hline \multicolumn{4}{|c|}{ TABLE 1 } \\
\hline Faculty Response Rates \\
\hline Architecture & $\begin{array}{c}\text { Questionnaires } \\
\text { Sent Out }\end{array}$ & $\begin{array}{c}\text { Number of } \\
\text { Responses Received }\end{array}$ & $\begin{array}{c}\text { Response Rate within } \\
\text { Research Population }\end{array}$ \\
\hline Art \& Design & 20 & 15 & $75 \%$ \\
\hline $\begin{array}{l}\text { All faculty teaching } \\
\text { on final year modules }\end{array}$ & 105 & 27 & $26 \%$ \\
\hline
\end{tabular}


researcher was especially well known to the Architecture faculty, being their subject librarian and the one who managed their library resources budget!

\section{British Faculty Responses}

As in the original research, ${ }^{23}$ the Architecture and Art and Design faculty were asked about:

- their perceptions of information literacy; and

- the actions they took to develop students' information literacy skills.

Faculty perceptions of information literacy were gauged by their responses to specific perception statements, first using the CILIP definition of information literacy; and, second, asking them whether they believed that students had reached this state by the end of their program. The faculty responses to the CILIP definition are shown in table 2 below. Their perceptions about whether students should have achieved an information-literate state by the end of their program are laid out in table 3.

Generally, this shows a positive affirmation for the CILIP definition of information literacy. Another reason for asking faculty to comment on this statement was to give them a definition on which they could base their opinion of whether students should be information literate by the end of their program, as shown in table 3.

The faculty opinions, about whether students should be information literate by the end of their program, are equally as strong as in the original research, which gave an overall 93 percent agreement (when you combine Strongly Agree and Agree together). In these subsequent studies, the Architecture faculty's agreement was exactly 93 percent, with Art and Design faculty giving an even stronger rating to the importance of information literacy with 98 percent overall agreement.

As with the previous research, it was anticipated that faculty would show a positive response to whether students should be information literate. It is a bit like global warming and energy efficiency: The majority of people feel that we should all do more to "save the planet" but not so many are willing to give up their cars to do so! The most pertinent question was always going to be this: What do faculty do to help

\begin{tabular}{|c|c|c|c|c|}
\hline \multicolumn{5}{|c|}{$\begin{array}{c}\text { TABLE } 2 \\
\text { DMU Faculty Responses on What Characterizes an Information Literate } \\
\text { Student (Using The CILIP Definition) }\end{array}$} \\
\hline $\begin{array}{l}\text { An information literate student is } \\
\text { one who knows when and why they } \\
\text { need information, where to find it, } \\
\text { and how to evaluate, use and com- } \\
\text { municate it in an ethical manner }\end{array}$ & $\begin{array}{c}\text { Strongly } \\
\text { Agree }\end{array}$ & Agree & Disagree & $\begin{array}{l}\text { Strongly } \\
\text { Disagree }\end{array}$ \\
\hline Architecture & $73 \%(11)$ & $20 \%(3)$ & $7 \%(1)$ & 0 \\
\hline Art \& Design & $63 \%(17)$ & $37 \%(10)$ & 0 & 0 \\
\hline \multicolumn{5}{|c|}{ TABLE 3} \\
\hline $\begin{array}{l}\text { Students should have achieved an } \\
\text { information literate state by the } \\
\text { end of their course }\end{array}$ & $\begin{array}{c}\text { Strongly } \\
\text { Agree }\end{array}$ & Agree & Disagree & $\begin{array}{l}\text { Strongly } \\
\text { Disagree }\end{array}$ \\
\hline Architecture & $60 \%(9)$ & $33 \%(5)$ & $7 \%(1)$ & 0 \\
\hline Art \& Design & $56 \%(15)$ & $42 \%(11)$ & $2 \%(1)$ & 0 \\
\hline $\begin{array}{l}\text { All faculty teaching on final year } \\
\text { modules }\end{array}$ & $54 \%(53)$ & $39 \%(38)$ & $3 \%(3)$ & $4 \%(4)$ \\
\hline
\end{tabular}


develop information-literate students? As before, this was measured against the SCONUL "Seven Pillars of Wisdom" model. The results are shown below for Architecture faculty in table 4 and Art and Design faculty in table 5, with numbers of respondents shown in parentheses.

Although the sample sizes were much smaller in the Architecture and Art and Design surveys, the response rates were higher and the similarity between all three survey results contributes to their validity. The 93 percent (Architecture) and 96 percent (Art and Design) acceptance of the "Seven Skills," as being those that they wish students to have acquired by the end of their program, compares favorably with the 91 percent acceptance in the 2004 survey. ${ }^{24}$ When the numbers for columns B, C, and D are combined, this gives a total of 53 percent (Architecture) and 56 percent (Art and Design) to show the level of activity undertaken by faculty to support the "Seven Skills," either by teaching, assessing, or developing them through student-centered learning. This compares to a 55 percent level of activity in the previous study and provides extra weight to the following argument: If faculty want students to have these skills, why are they not doing more to ensure their development? Why leave it to the process of osmosis? As there is a lower level of activity to help students acquire the skills, it is hardly surprising that figures are not high for the faculty responses in column E, relating to which skills it is felt that students have acquired by the end of their programs. These come to a total of 53 percent for Architecture and 59 percent for Art and Design, which reveals that these faculty feel that just over half

\begin{tabular}{|c|l|c|c|c|c|c|}
\hline \multicolumn{7}{|c|}{ TABLE 4 } \\
\multicolumn{7}{|c|}{ Architecture Faculty Responses to the "Seven Skills" } \\
\hline & SKILLS & A & B & C & D & E \\
\hline 1 & The ability to recognize a need for information. & $\begin{array}{c}93 \% \\
(14)\end{array}$ & $\begin{array}{c}80 \% \\
(12)\end{array}$ & $\begin{array}{c}80 \% \\
(12)\end{array}$ & $\begin{array}{c}40 \% \\
(6)\end{array}$ & $\begin{array}{c}73 \% \\
(11)\end{array}$ \\
\hline 2 & $\begin{array}{l}\text { The ability to distinguish ways in which the in- } \\
\text { formation "gap" may be addressed, e.g. knowl- } \\
\text { edge of appropriate and relevant resources. }\end{array}$ & $\begin{array}{c}100 \% \\
(15)\end{array}$ & $\begin{array}{c}60 \% \\
(9)\end{array}$ & $\begin{array}{c}73 \% \\
(11)\end{array}$ & $\begin{array}{c}33 \% \\
(5)\end{array}$ & $\begin{array}{c}67 \% \\
(10)\end{array}$ \\
\hline 3 & $\begin{array}{l}\text { The ability to construct strategies for locat- } \\
\text { ing information, e.g. to develop a systematic } \\
\text { method appropriate for the need. }\end{array}$ & $\begin{array}{c}100 \% \\
(15)\end{array}$ & $\begin{array}{c}47 \% \\
(7)\end{array}$ & $\begin{array}{c}80 \% \\
(12)\end{array}$ & $\begin{array}{c}13 \% \\
(2)\end{array}$ & $\begin{array}{c}47 \% \\
(7)\end{array}$ \\
\hline 4 & $\begin{array}{l}\text { The ability to locate and access information, } \\
\text { e.g. to use appropriate indexing and abstract- } \\
\text { ing services, citation indexes, and databases. }\end{array}$ & $\begin{array}{c}93 \% \\
(14)\end{array}$ & $\begin{array}{c}60 \% \\
(9)\end{array}$ & $\begin{array}{c}73 \% \\
(11)\end{array}$ & $\begin{array}{c}3 \% \\
(8)\end{array}$ & $\begin{array}{c}60 \% \\
(9)\end{array}$ \\
\hline 5 & $\begin{array}{l}\text { The ability to compare and evaluate infor- } \\
\text { mation obtained from different sources, e.g. } \\
\text { awareness of bias and authority issues. }\end{array}$ & $\begin{array}{c}100 \% \\
(15)\end{array}$ & $\begin{array}{c}47 \% \\
(7)\end{array}$ & $\begin{array}{c}53 \% \\
(8)\end{array}$ & $\begin{array}{c}3 \% \\
(8)\end{array}$ & $\begin{array}{c}27 \% \\
(4)\end{array}$ \\
\hline 6 & $\begin{array}{l}\text { The ability to organize, apply, and communi- } \\
\text { cate information to others in ways appropriate } \\
\text { to the situation, e.g. to cite bibliographic refer- } \\
\text { ences in project reports and dissertations. }\end{array}$ & $\begin{array}{c}100 \% \\
(15)\end{array}$ & $\begin{array}{c}73 \% \\
(11)\end{array}$ & $\begin{array}{c}73 \% \\
(11)\end{array}$ & $\begin{array}{c}73 \% \\
(11)\end{array}$ & $\begin{array}{c}53 \% \\
(8)\end{array}$ \\
\hline 7 & $\begin{array}{l}\text { The ability to synthesize and build upon exist- } \\
\text { ing information, contributing to the creation of } \\
\text { new knowledge. }\end{array}$ & $\begin{array}{c}80 \% \\
(12)\end{array}$ & $\begin{array}{c}27 \% \\
(4)\end{array}$ & $\begin{array}{c}47 \% \\
(7)\end{array}$ & $\begin{array}{c}53 \% \\
(8)\end{array}$ & $\begin{array}{c}40 \% \\
(6)\end{array}$ \\
\hline & $\begin{array}{l}\text { Average responses to seven skills overall } \\
(14)\end{array}$ & $\begin{array}{c}53 \% \\
(8)\end{array}$ & $\begin{array}{c}67 \% \\
(10)\end{array}$ & $\begin{array}{c}47 \% \\
(7)\end{array}$ & $\begin{array}{c}53 \% \\
(8)\end{array}$ \\
\hline
\end{tabular}




\begin{tabular}{|l|l|c|c|c|c|c|}
\hline \multicolumn{7}{|c|}{ AABLE 5 } \\
\multicolumn{7}{|c|}{ Art \& Design Faculty Responses to the "Seven Skills" } \\
\hline & SKILLS & A & B & C & D & E \\
\hline 1 & The ability to recognize a need for information. & $\begin{array}{c}93 \% \\
(25)\end{array}$ & $\begin{array}{c}63 \% \\
(17)\end{array}$ & $\begin{array}{c}70 \% \\
(19)\end{array}$ & $\begin{array}{c}48 \% \\
(13)\end{array}$ & $\begin{array}{c}63 \% \\
(17)\end{array}$ \\
\hline 2 & $\begin{array}{l}\text { The ability to distinguish ways in which the infor- } \\
\text { mation "gap" may be addressed, e.g. knowledge } \\
\text { of appropriate and relevant resources. }\end{array}$ & $\begin{array}{c}93 \% \\
(25)\end{array}$ & $\begin{array}{c}56 \% \\
(15)\end{array}$ & $\begin{array}{c}63 \% \\
(17)\end{array}$ & $\begin{array}{c}4 \% \\
(12)\end{array}$ & $\begin{array}{c}59 \% \\
(16)\end{array}$ \\
\hline 3 & $\begin{array}{l}\text { The ability to construct strategies for locating } \\
\text { information, e.g. to develop a systematic method } \\
\text { appropriate for the need. }\end{array}$ & $\begin{array}{c}100 \% \\
(27)\end{array}$ & $\begin{array}{c}56 \% \\
(15)\end{array}$ & $\begin{array}{c}52 \% \\
(14)\end{array}$ & $\begin{array}{c}41 \% \\
(11)\end{array}$ & $\begin{array}{c}48 \% \\
(13)\end{array}$ \\
\hline 4 & $\begin{array}{l}\text { The ability to locate and access information, } \\
\text { e.g. to use appropriate indexing and abstracting } \\
\text { services, citation indexes, and databases. }\end{array}$ & $\begin{array}{c}96 \% \\
(26)\end{array}$ & $\begin{array}{c}48 \% \\
(13)\end{array}$ & $\begin{array}{c}63 \% \\
(17)\end{array}$ & $\begin{array}{c}41 \% \\
(11)\end{array}$ & $\begin{array}{c}59 \% \\
(16)\end{array}$ \\
\hline 5 & $\begin{array}{l}\text { The ability to compare and evaluate information } \\
\text { obtained from different sources, e.g. awareness of } \\
\text { bias and authority issues. }\end{array}$ & $\begin{array}{c}100 \% \\
(27)\end{array}$ & $\begin{array}{c}59 \% \\
(16)\end{array}$ & $\begin{array}{c}67 \% \\
(18)\end{array}$ & $\begin{array}{c}56 \% \\
(15)\end{array}$ & $\begin{array}{l}52 \% \\
(14)\end{array}$ \\
\hline 6 & $\begin{array}{l}\text { The ability to organize, apply, and communicate } \\
\text { information to others in ways appropriate to the } \\
\text { situation, e.g. to cite bibliographic references in } \\
\text { project reports and dissertations. }\end{array}$ & $\begin{array}{c}100 \% \\
(27)\end{array}$ & $\begin{array}{c}70 \% \\
(19)\end{array}$ & $\begin{array}{c}70 \% \\
(19)\end{array}$ & $\begin{array}{c}59 \% \\
(16)\end{array}$ & $\begin{array}{c}70 \% \\
(19)\end{array}$ \\
\hline 7 & $\begin{array}{l}\text { The ability to synthesize and build upon existing } \\
\text { information, contributing to the creation of new } \\
\text { knowledge. }\end{array}$ & $\begin{array}{c}93 \% \\
(25)\end{array}$ & $\begin{array}{c}59 \% \\
(16)\end{array}$ & $\begin{array}{c}59 \% \\
(16)\end{array}$ & $\begin{array}{c}48 \% \\
(13)\end{array}$ & $\begin{array}{l}52 \% \\
(14)\end{array}$ \\
\hline & $\begin{array}{l}\text { Average responses to seven skills overall } \\
(26)\end{array}$ & $\begin{array}{c}59 \% \\
(16)\end{array}$ & $\begin{array}{c}63 \% \\
(17)\end{array}$ & $\begin{array}{c}48 \% \\
(13)\end{array}$ & $\begin{array}{c}59 \% \\
(16)\end{array}$ \\
\hline
\end{tabular}

of their graduating students leave in a state of information literacy. In summary:

- 93 percent of Architecture faculty want students to acquire information literacy skills

○ 53 percent are teaching/assessing/developing the skills in students

○ 53 percent believe that students do acquire the skills.

- 96 percent of Art and Design faculty want students to acquire information literacy skills

- 56 percent are teaching/assessing/developing the skills in students

○ 59 percent believe that students do acquire the skills.

\section{Is the Situation Any Better in the United States?}

In August 2006, the author moved to the United States and began working at The
College of New Jersey (TCNJ). As an institution, TCNJ is quite different from DMU. TCNJ is a small (around 6,000 students), highly selective four-year public college with an excellent reputation. The students are quite motivated, and both retention and graduation rates are high. The college has a strong liberal arts foundation but offers degree programs across seven schools:

- Arts and Communication (known as Art, Media, and Music at the time of the research)

- Business

- Culture and Society

- Education

- Engineering

- Nursing, Health, and Exercise Science

- Science

In 2003 the college underwent a "transformation" to revise the curriculum from a General Education to a Liberal Arts 
foundation. Information Literacy was listed within the Goals and Outcomes of the redesigned curriculum:

"Students will be able to navigate information resources using digital and other technology in order to support their studies, and their efforts to communicate their findings persuasively.

- The information literate student determines the nature and extent of the information needed.

- The information literate student accesses needed information effectively and efficiently.

- The information literate student evaluates information and its sources critically and incorporates selected information into his or her knowledge base and value system.

- The information literate student, individually or as a member of a group, uses information effectively to accomplish a specific purpose.

- The information literate student understands many of the economic, legal, and social issues surrounding the use of information and accesses and uses information ethically and legally." 25

\section{The American Study}

This written commitment to information literacy made the author more hopeful that faculty might be relying less on the process of osmosis to incorporate the skills within the curriculum. It was hoped that the research on faculty perceptions of information literacy at TCNJ could be undertaken during the fall 2006 semester. However, the process of getting the questionnaire approved by the Institutional Review Board took longer than expected, and the research was conducted in January/February 2007.

The same, shortened questionnaire that was used with Architecture and Art and Design faculty at DMU was customized for an American audience. Terminology and spellings were changed, and the American Library Association's definition of information literacy was reinstated.
In both the British and American studies, faculty were asked to comment upon their level of agreement with two other statements, which have not been reported upon previously but are worthy of inclusion in this report. These statements were:

- Students learn research skills better if they are assessed on them;

- Students demonstrate the use of a coping mechanism rather than an information strategy.

The second of these statements is based on a comment made by Gloria Leckie in her excellent article on faculty assumptions about the undergraduate research process: "They [undergraduate students] do not think in terms of an informationseeking strategy, but rather in terms of a coping strategy." 26

It was a conscious decision to retain the skills list from SCONUL's "Seven Pillars of Wisdom" rather than use the Association of College and Research Libraries (ACRL) Information Literacy Competency Standards for Higher Education..$^{27}$ It was felt that the "Seven Pillars" skills needed to be retained to ensure a more direct and accurate comparison between the British and American faculty responses. Also, as was found by Gullikson, ${ }^{28}$ the ACRL Standards are more complex and would make for a longer questionnaire, which faculty may be more reluctant to complete. The full questionnaire, used in the American study, can be found in Appendix 1.

Although time and technology had moved on since the original research conducted in the United Kingdom, it was decided to follow the same methodology to more accurately compare the results. Therefore, the questionnaire was provided on paper and distributed via the internal mail. The size of the research population was of a comparable proportion to the previous sample of module leaders teaching on final (senior) year courses, with 331 questionnaires being distributed compared to 478 at DMU.29 Questionnaires were not sent to adjunct professors as they are more difficult to communicate with internally. As with 
each of the three previous studies, the paper questionnaires were followed up with two e-mail reminders, with a gap of two weeks between each. However, the e-mail follow-ups did not go out to all potential respondents since strict limitations are put on faculty distribution lists at the college and it was only possible to send an e-mail of this nature (that is, nonofficial college business) to a list from which faculty are at liberty to opt out.

The response rate, even after the e-mail follow-ups, was a disappointing 18 percent (see table 6). Possible reasons for this:

- Faculty might have preferred an online questionnaire;

- The researcher was less well known to faculty than at her previous institution;

- The e-mail reminders were not reaching the required population.

While the low response rates make it more difficult to draw representative conclusions in some areas, they are not untypical of response rates from other faculty surveys undertaken by librarians. (Gullikson, ${ }^{30}$ surveying faculty in a Canadian university, got a 21 percent response rate. Singh, ${ }^{31}$ working with faculty in Journalism and Mass Communication got a 22.3 percent response rate.) Also, the faculty response rate to the TCNJ Library's LibQual survey was only 19.6 percent in 2005. There are some interesting comparisons with the response rates from the previous institutional research. In both the British and American studies, the Business faculty produced more viable samples with 25 percent and 27 percent response rates, respectively. In the British study, the researcher was also not well known to the Business faculty. In the American study, the response rate from Nursing, Health and Exercise Science (5 percent) was particularly disappointing as the comparable (albeit much larger) school in the United Kingdom (Health and Life Sciences) produced a response rate of 30 percent.

\section{American Faculty Responses}

The same perception statements were used based on the ALA definition of information literacy and asking faculty whether they felt that students had reached this state by the end of their undergraduate degree program. The TCNJ faculty responses to the ALA definition are given in table 7. Their perceptions about whether students have achieved an informationliterate state are shown in table 8.

Although individual departmental response numbers are low, the overall agreement with the definition of an information-literate student is high, with 85 percent strongly agreeing and 15 percent agreeing. The agreement level is actually the highest received in all of the surveys. The previous test of the ALA definition was with the original DMU

\begin{tabular}{|l|c|c|c|}
\hline \multicolumn{4}{|c|}{ TABLE 6 } \\
TCNJ Faculty Response Rates \\
\hline School & $\begin{array}{c}\text { Questionnaires } \\
\text { Sent Out }\end{array}$ & $\begin{array}{c}\text { Number of } \\
\text { Responses Received }\end{array}$ & $\begin{array}{c}\text { Response Rate } \\
\text { within School }\end{array}$ \\
\hline Art, Media \& Music & 28 & 1 & $4 \%$ \\
\hline Business & 33 & 9 & $27 \%$ \\
\hline Culture \& Society & 115 & 24 & $21 \%$ \\
\hline Education & 48 & 15 & $31 \%$ \\
\hline Engineering & 23 & 3 & $13 \%$ \\
\hline $\begin{array}{l}\text { Nursing, Health \& Exercise } \\
\text { Science }\end{array}$ & 20 & 1 & $5 \%$ \\
\hline Science & 64 & 8 & $13 \%$ \\
\hline TOTAL & 331 & 61 & $18 \%$ \\
\hline
\end{tabular}


TABLE 7

TCNJ Faculty Responses on What Characterizes an Information Literate Student (Using ALA Definition)

\begin{tabular}{|l|c|c|c|c|}
\hline $\begin{array}{l}\text { An information literate student is one } \\
\text { who can recognize when information is } \\
\text { needed and have the ability to locate, } \\
\text { evaluate and use effectively the needed } \\
\text { information }\end{array}$ & $\begin{array}{l}\text { Strongly } \\
\text { Agree }\end{array}$ & Agree & Disagree & $\begin{array}{l}\text { Strongly } \\
\text { Disagree }\end{array}$ \\
\hline Art, Media \& Music & 0 & $100 \%(1)$ & 0 & 0 \\
\hline Business & $100 \%(9)$ & 0 & 0 & 0 \\
\hline Culture \& Society & $75 \%(18)$ & $25 \%(6)$ & 0 & 0 \\
\hline Education & $87 \%(13)$ & $13 \%(2)$ & 0 & 0 \\
\hline Engineering & $100 \%(3)$ & 0 & 0 & 0 \\
\hline Nursing, Health \& Exercise Science & $100 \%(1)$ & 0 & 0 & 0 \\
\hline Science & $100 \%(8)$ & 0 & 0 & 0 \\
\hline TOTAL & $85 \%(52)$ & $15 \%(9)$ & 0 & 0 \\
\hline
\end{tabular}

sample where 65 percent strongly agreed and 32 percent agreed..$^{22}$ Subsequently, the CILIP definition of information literacy was used, and this did not receive such positive agreement (see tables 2 and 3 above). In discussion with faculty at DMU, it appeared that some people were not comfortable with the word "ethical" being included, especially those for whom the word had a specific connotation, such as medical professionals.

Responses from TCNJ faculty about whether they believe that students should be information literate by the end of their programs are equally encouraging (as shown in table 8 ).

Combining the Strongly Agree and Agree responses together produces another high level of faculty support (98 percent) for students to be information literate by the end of their program. This is in line with the January 2006 survey, undertaken with Art and Design faculty at DMU, but greater than the 93 percent overall agreement within the British institution (as shown in table 3).

\begin{tabular}{|c|c|c|c|c|}
\hline \multicolumn{5}{|c|}{$\begin{array}{c}\text { TABLE } 8 \\
\text { TCNJ Faculty on Students Being Information Literate }\end{array}$} \\
\hline $\begin{array}{l}\text { Students should have achieved an } \\
\text { information literate state by the end } \\
\text { of their degree program }\end{array}$ & $\begin{array}{l}\text { Strongly } \\
\text { Agree }\end{array}$ & Agree & Disagree & $\begin{array}{l}\text { Strongly } \\
\text { Disagree }\end{array}$ \\
\hline Art, Media \& Music & $100 \%(1)$ & 0 & 0 & 0 \\
\hline Business & $67 \%(6)$ & $33 \%(3)$ & 0 & 0 \\
\hline Culture \& Society & $83 \%(20) *$ & $13 \%(3)$ & $4 \%(1)$ & 0 \\
\hline Education & $93 \%(14)$ & $7 \%(1)$ & 0 & 0 \\
\hline Engineering & $100 \%(3)$ & 0 & 0 & 0 \\
\hline Nursing, Health \& Exercise Science & $100 \%(1)$ & 0 & 0 & 0 \\
\hline Science & $75 \%(6)$ & $25 \%(2)$ & 0 & 0 \\
\hline TOTAL & $83 \%(51)$ & $15 \%(9)$ & $2 \%(1)$ & 0 \\
\hline
\end{tabular}


The responses to the other two perception statements, on which faculty were asked to specify their level of agreement, are shown along with the results from the original research in $2004^{33}$ in figures 1 and 2 . These are reported at an institutional level, rather than departmental, for simplicity and to provide more valid comparative data.

For many years, librarians have been saying that students learn research skills better if they are assessed on them. ${ }^{34} \mathrm{We}$ recognize that students are more motivated by the prospect of a grade that counts rather than the fact that information skills are transferable and can make a positive contribution to lifelong learning. The recognition by faculty that assessment of these skills is important can serve as useful "ammunition" when fighting the information literacy "battle." The overall agreement level (combining Strongly Agree and Agree responses) of 91 percent among the American faculty, as opposed to 85 percent for the British faculty, could be even more encouraging for American librarians.

The next statement on which faculty were asked to comment provided some interesting feedback, particularly from the American faculty. Gloria Leckie's suggestion that students display a coping strategy rather than an information strategy $\mathrm{y}^{35}$ is something that is recognizable to many librarians at the reference desk. She talks about faculty as the "expert" researchers who have perhaps forgotten what it was like to be an undergraduate "novice" researcher, with the additional problems of information overload, working part-time, and coming from a more diverse student body. Valentine also found evidence of this, saying that "students often used very chaotic, what they themselves termed 'random', methods for finding materials for their papers." 36 The purpose of the question within each of the surveys was to test the extent to which faculty perceived that students are actually formulating information strategies.

There are similar levels of overall agreement with a combined (Strongly Agree and Agree responses) 63 percent of British faculty and 57 percent of American faculty believing that students demonstrate the use of a coping mechanism. What is interesting is how many faculty did not answer this question (25 percent of the American and 10 percent of the British faculty). Of the 15 American faculty who did not answer this question, 11 actually wrote on the questionnaire that they did not understand what the question meant. As the original survey was tested on a sample of British faculty, to check for their understanding of the questions, then on American library colleagues for terminology, it is difficult to discern the precise nature of the problem with this question. It is perhaps worthy of further research with American faculty on their understanding

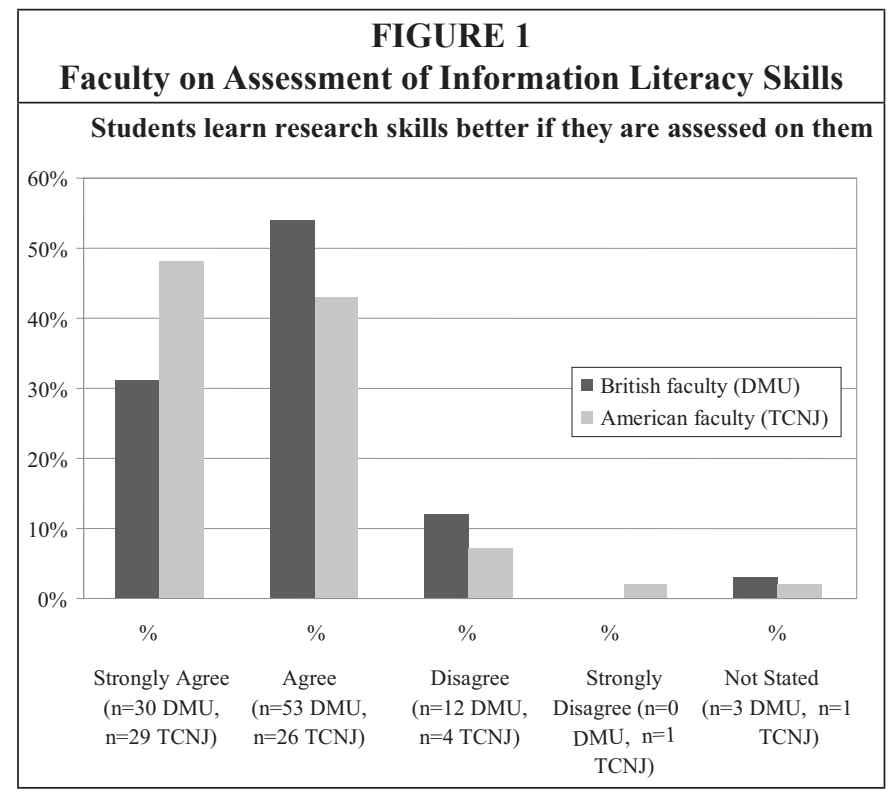


of "an information strategy," as this is such a foundational precept of the ACRL Information Literacy Competency Standards. (Shelley Gullikson's ${ }^{37}$ research on faculty perceptions of the ACRL Standards also found that Standard 2.2- "The information literate student constructs and implements effectively-designed search strategies" ${ }^{\prime 38}$ - did not rank so highly in the learning outcomes valued by faculty.) Librarians on both sides of the Atlantic can probably point to many instances where they have observed students demonstrating the lack of an information strategy, and this finding gives weight to Leckie's argument that "there is likely to be a large disjuncture between the expectations of the faculty member as the expert researcher and the capabilities of the undergraduate as the novice researcher." ${ }^{39}$

\section{How the "Seven Pillars of Wisdom" Rated with American Faculty}

As previously stated, the "Seven Pillars of Wisdom" model was retained in the American study to provide a direct

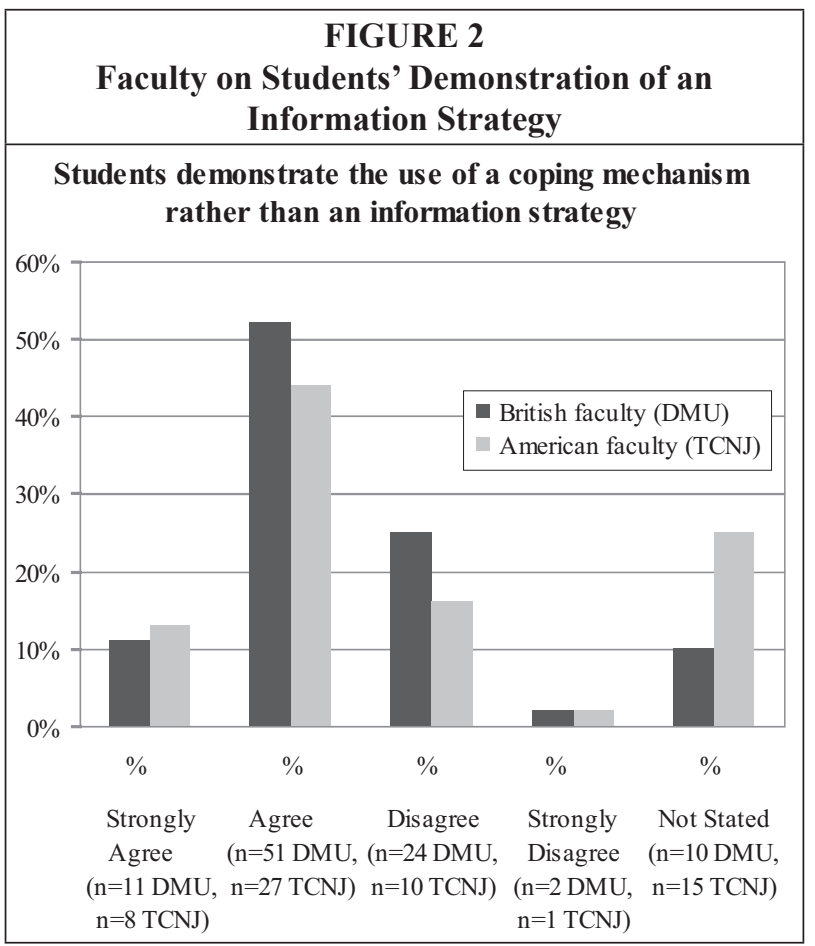

comparison with the British research. None of the faculty were told that the skills came from a specific model, which enabled them to be viewed on their own merit as a listing of information literacy skills. The language and terminology was changed for the American survey (see Appendix 1) so that each of the five columns was rated as to which of the following skills:

A. Do you wish students to have acquired by the end of their degree program?

B. Are specifically taught in courses in which you are involved?

C. Are developed through studentcentered learning in courses in which you are involved?

D. Are assessed within courses that you teach?

E. Do you feel that students have acquired by the end of their degree program?

The results are shown below for TCNJ faculty in table 9 with numbers of respondents shown in parentheses.

Overall, the seven skills that are listed are those that 88 percent of the TCNJ respondents wish for their students to have acquired by the time that they graduate, with a small variation between the most important Skill 1-the ability to recognize a need for information - at 92 percent and the least important Skill 6-the ability to organize, apply, and communicate information to others in ways appropriate to the situation-at 83 percent. Columns B, C, and D indicate the level of activity undertaken by faculty to embed the skills into student learning, either by specifically teaching (B), assessing (D), or devel- 


\begin{tabular}{|c|c|c|c|c|c|c|}
\hline \multicolumn{7}{|c|}{$\begin{array}{l}\text { TABLE } 9 \\
\text { TCNJ Faculty Responses to the "Seven Skills" }\end{array}$} \\
\hline & SKILLS & $\mathbf{A}$ & B & $\mathbf{C}$ & D & $\mathbf{E}$ \\
\hline 1 & The ability to recognize a need for information. & $\begin{array}{l}92 \% \\
(55)\end{array}$ & $\begin{array}{l}65 \% \\
(39)\end{array}$ & $\begin{array}{l}67 \% \\
(40)\end{array}$ & $\begin{array}{l}53 \% \\
(32)\end{array}$ & $\begin{array}{l}63 \% \\
(35)\end{array}$ \\
\hline 2 & $\begin{array}{l}\text { The ability to distinguish ways in which the infor- } \\
\text { mation "gap" may be addressed, e.g. knowledge of } \\
\text { appropriate and relevant resources. }\end{array}$ & $\begin{array}{l}90 \% \\
(54)\end{array}$ & $\begin{array}{l}65 \% \\
(39)\end{array}$ & $\begin{array}{l}55 \% \\
(33)\end{array}$ & $\begin{array}{l}47 \% \\
(28)\end{array}$ & $\begin{array}{l}45 \% \\
(27)\end{array}$ \\
\hline 3 & $\begin{array}{l}\text { The ability to construct strategies for locating } \\
\text { information, e.g. to develop a systematic method } \\
\text { appropriate for the need. }\end{array}$ & $\begin{array}{l}90 \% \\
(54)\end{array}$ & $\begin{array}{l}38 \% \\
(23)\end{array}$ & $\begin{array}{l}50 \% \\
(30)\end{array}$ & $\begin{array}{l}32 \% \\
(19)\end{array}$ & $\begin{array}{l}47 \% \\
(28)\end{array}$ \\
\hline 4 & $\begin{array}{l}\text { The ability to locate and access information, e.g. to } \\
\text { use appropriate indexing and abstracting services, } \\
\text { citation indexes, and databases. }\end{array}$ & $\begin{array}{l}85 \% \\
(51)\end{array}$ & $\begin{array}{l}47 \% \\
(28)\end{array}$ & $\begin{array}{l}53 \% \\
(32)\end{array}$ & $\begin{array}{l}40 \% \\
(24)\end{array}$ & $\begin{array}{l}53 \% \\
(32)\end{array}$ \\
\hline 5 & $\begin{array}{l}\text { The ability to compare and evaluate information } \\
\text { obtained from different sources, e.g. awareness of } \\
\text { bias and authority issues. }\end{array}$ & $\begin{array}{l}90 \% \\
(54)\end{array}$ & $\begin{array}{l}62 \% \\
(37)\end{array}$ & $\begin{array}{l}55 \% \\
(33)\end{array}$ & $\begin{array}{l}57 \% \\
(34)\end{array}$ & $\begin{array}{l}37 \% \\
(22)\end{array}$ \\
\hline 6 & $\begin{array}{l}\text { The ability to organize, apply, and communicate } \\
\text { information to others in ways appropriate to the } \\
\text { situation, e.g. to cite bibliographic references in } \\
\text { project reports and dissertations. }\end{array}$ & $\begin{array}{l}83 \% \\
(50)\end{array}$ & $\begin{array}{l}70 \% \\
(42)\end{array}$ & $\begin{array}{l}65 \% \\
(39)\end{array}$ & $\begin{array}{l}68 \% \\
(41)\end{array}$ & $\begin{array}{l}52 \% \\
(31)\end{array}$ \\
\hline 7 & $\begin{array}{l}\text { The ability to synthesize and build upon existing } \\
\text { information, contributing to the creation of new } \\
\text { knowledge. }\end{array}$ & $\begin{array}{l}88 \% \\
(53)\end{array}$ & $\begin{array}{l}63 \% \\
(38)\end{array}$ & $\begin{array}{l}53 \% \\
(32)\end{array}$ & $\begin{array}{l}55 \% \\
(33)\end{array}$ & $\begin{array}{l}47 \% \\
(28)\end{array}$ \\
\hline & Average responses to seven skills overall & $\begin{array}{l}88 \% \\
(53)\end{array}$ & $\begin{array}{l}63 \% \\
(35)\end{array}$ & $\begin{array}{l}57 \% \\
(34)\end{array}$ & $\begin{array}{l}50 \% \\
(30)\end{array}$ & $\begin{array}{l}48 \% \\
\text { (29) }\end{array}$ \\
\hline
\end{tabular}

oping the skills through student-centered learning $(\mathrm{C})$. Combining the total number of responses together in columns B, C, and $\mathrm{D}$ produces an average of 54 percent of faculty who are taking these actions to develop their students' information literacy skills. Evidence of this lack of activity on the part of faculty is not just confined to this particular study. Singh ${ }^{40}$ reported that a large number of faculty, teaching in Journalism and Mass Communication programs, stated that their students' research skills were poor but they still did not include library instruction in their courses.

One of the most vital questions is whether faculty perceive students to have acquired the seven skills by the end of their degree program, and only 48 percent of the respondents believe this to be the case. In summary:
- 88 percent of TCNJ faculty want students to acquire information literacy skills

○ 54 percent are teaching/assessing/developing the skills in students

- 48 percent believe that students do acquire the skills.

Looking back at the TCNJ faculty responses to the statement "students learn research skills better if they are assessed on them," there was an encouraging 90 percent level of agreement (see figure 1). However, only 50 percent of the faculty who responded are actually assessing the seven skills in their courses (see table 9, column D). The most commonly taught and assessed skill is Skill 6, which correlated with the findings in the British study. ${ }^{41}$ Skill 5, which relates to the evaluation of information, is felt to be the least acquired, with only 37 percent providing affirmation. This is certainly 
an area in which librarians can make a positive contribution.

\section{Bridging the Information Literacy Skills Gap "Across the Pond"}

Despite this author's hopefulness that information skills might be better incorporated within the curriculum of a more academically selective American higher education institution, this was not found to be the case. At each institution a summation was made based on faculty responses to the skills outlined in the SCONUL model. Results were tabulated by department to show:

- the overall importance of the seven skills in total;

- what is done to embed the teaching and learning of the seven skills, by adding together the responses for columns B, C, and D; and

- the gap between the importance of the skills and the actions taken to embed them.

Table 10 shows the results from DMU; table 11, the results from TCNJ.

The gap between the responses on the overall skills that faculty wish for their students to acquire and the activities undertaken to develop the skills is 31 percent in the United States and 36 percent in the United Kingdom. At DMU, only one department (Health and Life Sciences) rated the importance of the skills at below 90 percent. At TCNJ, only three out of the seven departments gave a rating above 90 percent, namely Art, Media and Music; Nursing, Health and Exercise Science; and Culture and Society. Generally, it is difficult to draw realistic comparisons between discipline areas due to the lower response rates at TCNJ. An interesting parallel is with the Education departments, where both share a 31 percent gap between the importance of the skills to faculty and the actions taken to incorporate them within teaching and learning.

The original survey at DMU did not ask whether faculty felt that students had actually acquired the seven skills by the end of their program. However, Architecture and Art and Design faculty were asked to rate this attainment (in column E) and they did so at 53 (table 4) and 59 percent (table 5) respectively. Correspondingly, only 48 percent of TCNJ faculty (table 9) believed that their students had acquired the seven skills by the time that they graduated.

The skill that was felt to be the least acquired by students in the opinion of both TCNJ (37 percent) and DMU Architecture (27 percent) faculty was Skill 5: the ability to compare and evaluate information obtained from different sources. Both the DMU institutional respondents and the

\begin{tabular}{|l|c|c|c|}
\hline \multicolumn{5}{|c|}{ TABLE 10 } \\
\hline Faculty & $\begin{array}{c}\text { Importance of } \\
\text { skills to faculties } \\
\text { \% response }\end{array}$ & $\begin{array}{c}\text { Actions taken to } \\
\text { embed skills in } \\
\text { student learning } \\
\text { \% response }\end{array}$ & $\begin{array}{c}\text { Gap between } \\
\text { importance \& } \\
\text { actions } \\
\text { \% response }\end{array}$ \\
\hline Art \& Design & 93 & 56 & 37 \\
\hline Business \& Law & 94 & 48 & 46 \\
\hline $\begin{array}{l}\text { Computing Sciences } \\
\text { \& Engineering }\end{array}$ & 90 & 31 & 59 \\
\hline $\begin{array}{l}\text { Education \& } \\
\text { Contemporary Studies }\end{array}$ & 92 & 61 & 31 \\
\hline Health \& Life Sciences & 87 & 68 & 19 \\
\hline Humanities & 95 & 70 & 25 \\
\hline TOTAL & 91 & 55 & 36 \\
\hline
\end{tabular}




\section{TABLE 11}

TCNJ Faculty on Importance of Skills and Actions Taken to Embed

\begin{tabular}{|l|c|c|c|}
\hline $\begin{array}{l}\text { Schools \& } \\
\text { Departments }\end{array}$ & $\begin{array}{c}\text { Importance of } \\
\text { skills to faculties } \\
\text { \% response }\end{array}$ & $\begin{array}{c}\text { Actions taken to } \\
\text { embed skills in } \\
\text { student learning } \\
\text { \% response }\end{array}$ & $\begin{array}{c}\text { Gap between } \\
\text { importance \& } \\
\text { actions } \\
\text { \% response }\end{array}$ \\
\hline Art, Media \& Music & 100 & 72 & 28 \\
\hline Business & 78 & 60 & 18 \\
\hline Culture \& Society & 91 & 60 & 31 \\
\hline Education & 80 & 49 & 31 \\
\hline Engineering & 67 & 67 & 0 \\
\hline $\begin{array}{l}\text { Nursing, Health \& } \\
\text { Exercise Science }\end{array}$ & 100 & 95 & 5 \\
\hline Science & 88 & 42 & 46 \\
\hline TOTAL & 88 & 57 & 31 \\
\hline
\end{tabular}

TCNJ faculty ranked Skill 1 - the ability to recognize a need for information - as the most important for students to acquire, at 97 and 92 percent respectively. The British respondents felt that Skill 7-the ability to synthesize and build upon existing information, contributing to the creation of new knowledge-was the least important for undergraduate students to acquire. This is in line with the original thinking behind the "Seven Pillars" model, which suggested that this might be more attributable to (post)graduate learning. ${ }^{42}$ However, this skill (which closely equates to the ACRL's Standard 3.3: "The information literate student synthesizes main ideas to construct new concepts" ${ }^{\prime 4}$ ) was ranked more highly at TCNJ, with 88 percent of faculty wishing for their students to acquire it. The American respondents felt that Skill 6-the ability to organize, apply, and communicate information to others in ways appropriate to the situation - was the least important for their students to acquire. Interestingly, librarians at DMU were often asked to teach citation referencing to students, but this is not the case at TCNJ. However, there does appear to be a greater overall commitment to the importance of academic integrity at TCNJ, where it is a significant component of the First Seminar Program for freshman students.
It is appreciated that the faculty who responded at TCNJ represented just over 18 percent of the total teaching faculty. However, the close correlation with the results obtained in the British study does contribute toward some greater validity. Responses were not plentiful enough to draw any meaningful conclusions between specific disciplines, but the general picture is that the information literacy skills gap is a transatlantic challenge for librarians to address.

\section{How to Respond to the Transatlantic Challenge?}

Librarians have long since been aware that it is a challenge to get information literacy incorporated into the curriculum and to have appropriate bibliographic instruction delivered to students. As previously stated, students are often only prepared to make the effort if they receive some reward, usually in the form of recorded credits. Regardless of that, it is also the sensible option for information literacy to be embedded into the curriculum of the subject discipline in which the students have chosen to invest their time. ${ }^{44}$ This enables information literacy to be contextualized and, one hopes, even valued as a relevant work/ life skill. 
As any presenter/teacher knows, it is imperative to "know your audience" to ensure that your content is relevant. This was the main purpose of this research. In the United Kingdom, the main language for information literacy is taken from the SCONUL "Seven Pillars of Wisdom" model.$^{45}$ In the United States, the language used comes from the ACRL's Information Literacy Competency Standards for Higher Education. ${ }^{46}$ This research, and that of Shelley Gullikson, ${ }^{47}$ have provided starting points to test whether faculty understand the language and share the philosophy that underpins it. To quote Anita Cannon, "In particular, since it is widely acknowledged that faculty cooperation is essential to a successful library instruction program, the needs, attitudes, and preferences of the faculty concerned should be well known and taken into consideration before embarking on any new plan of action in this area." 48 There are differences in the skills valued by faculty, within specific subject disciplines. It is not advisable to approach faculty with a "one size fits all" information literacy plan or package. Specific skills will matter to certain disciplines at different times in a degree program and prove more relevant to the students if they are introduced at the appropriate time.

Ascertaining the perceptions and attitudes of your faculty is just the first challenge. The next thing is to work on converting their support for the concept of information literacy into its greater inclusion in the curriculum. If you want a good plan of action to follow, then look no further than Patricia Senn Breivik's book "Student Learning in the Information Age." ${ }^{49}$ In it, she devotes a chapter to "Moving Forward" where she talks of obtaining a campus commitment to information literacy and, along the way: asking questions, providing a common vocabulary, conducting a campus audit, selling the vision, and celebrating success.
Following Weetman's research at DMU, these kinds of activities were undertaken to gain institutional approval of an Information Literacy Framework. ${ }^{50}$ Having ascertained the faculty's perceptions of information literacy, a framework was developed that was based on the "Seven Pillars" model, which had passed the previous "audit test." The language and principles were tested on faculty "critical friends" before being presented to departmental Teaching and Learning Committees, where the vision was "sold." The framework itself was designed to look like a course template as something that would be instantly recognizable to faculty. It also included a good practice example for each faculty (school) to show how information literacy had been incorporated within specific programs. Having taken these foundational steps, the framework was easily approved by the University Teaching and Learning Committee and then included as a requirement in the Program Developer's Guide, which was produced by the Department of Academic Quality and distributed to all faculty.

McGuinness $^{51}$ also recommends that librarians need to promote information literacy more widely by taking the message to faculty in their own environment, targeting educational and disciplinary conferences, workshops, and journals. Faculty need to not only be educated on the pedagogical value of information literacy but also shown examples of how and where it has been successfully embedded in the curriculum. Osmosis does not work for the development of information literacy, but neither does it work for effective collaboration between librarians and faculty. There is an apparent gap between the information literacy skills that faculty want their students to have and those that they actively support and develop. It is a gap that librarians on both sides of the Atlantic are best placed to fill as bridge builders. 


\section{APPENDIX 1. Information Literacy Survey}

January 2007

Dear Colleague,

I am currently researching into the importance of information literacy for college students. I would greatly appreciate your assistance with this research by completing the following questionnaire and returning it to me by February 2, 2007. All replies will be treated in the strictest confidence and your personal anonymity is guaranteed. If you would prefer to receive the questionnaire electronically, please contact me on dacosta@ tcnj.edu.

Many thanks for your time.

Jacqui DaCosta, Information Literacy Librarian, TCNJ Library

To what extent do you agree with the following statements?

\begin{tabular}{|l|l|l|l|l|l|}
\hline & Statement & $\begin{array}{c}\text { Strongly } \\
\text { Agree }\end{array}$ & Agree & Disagree & $\begin{array}{l}\text { Strongly } \\
\text { Disagree }\end{array}$ \\
\hline 1 & $\begin{array}{l}\text { "Students learn research skills better if } \\
\text { they are assessed on them" }\end{array}$ & & & & \\
\hline 2 & $\begin{array}{l}\text { "Students demonstrate the use of a } \\
\text { coping mechanism rather than an infor- } \\
\text { mation strategy" }\end{array}$ & $\begin{array}{l}\text { "An information literate student is one } \\
\text { who can recognize when information } \\
\text { is needed and have the ability to locate, } \\
\text { evaluate and use effectively the needed } \\
\text { information" }\end{array}$ & & & \\
\hline 4 & $\begin{array}{l}\text { Using the statement given in question } \\
3, \text { to what extent do you agree that stu- } \\
\text { dents should have achieved this state } \\
\text { by the end of their degree program? }\end{array}$ & & & & \\
\hline
\end{tabular}

5. Which of the following skills:

A. Do you wish students to have acquired by the end of their degree program?

B. Are specifically taught in courses in which you are involved?

C. Are developed through student centered learning in courses in which you are involved?

D. Are assessed within courses that you teach?

E. Do you feel that students have acquired by the end of their degree program?

\begin{tabular}{|l|l|l|l|l|l|l|}
\hline & SKILLS & A & B & C & D & E \\
\hline i & $\begin{array}{l}\text { The ability to recognize a need for informa- } \\
\text { tion. }\end{array}$ & & & & & \\
\hline ii & $\begin{array}{l}\text { The ability to distinguish ways in which } \\
\text { the information "gap" may be addressed, } \\
\text { e.g. knowledge of appropriate and relevant } \\
\text { resources. }\end{array}$ & & & & & \\
\hline
\end{tabular}




\begin{tabular}{|c|c|c|c|c|c|c|}
\hline & SKILLS & A & B & C & D & $\mathbf{E}$ \\
\hline iii & $\begin{array}{l}\text { The ability to construct strategies for locating } \\
\text { information, e.g. to develop a systematic } \\
\text { method appropriate for the need. }\end{array}$ & & & & & \\
\hline iv & $\begin{array}{l}\text { The ability to locate and access information, } \\
\text { e.g. to use appropriate indexing and abstract- } \\
\text { ing services, citation indexes, and databases. }\end{array}$ & & & & & \\
\hline $\mathrm{v}$ & $\begin{array}{l}\text { The ability to compare and evaluate infor- } \\
\text { mation obtained from different sources, e.g. } \\
\text { awareness of bias and authority issues. }\end{array}$ & & & & & \\
\hline vi & $\begin{array}{l}\text { The ability to organize, apply, and communi- } \\
\text { cate information to others in ways appropri- } \\
\text { ate to the situation, e.g. to cite bibliographic } \\
\text { references in project reports and dissertations. }\end{array}$ & & & & & \\
\hline vii & $\begin{array}{l}\text { The ability to synthesize and build upon exist- } \\
\text { ing information, contributing to the creation } \\
\text { of new knowledge. }\end{array}$ & & & & & \\
\hline
\end{tabular}

Please tick as many as are relevant

6. Which course(s) do you teach (please give course numbers)?

Thank you. If you would like to know more about my research and/or receive a summary of the results, please give your name. 


\section{Notes}

1. Larry Hardesty, Faculty and the Library: The Undergraduate Experience (Norwood, N.J.: Ablex Publishing, 1991).

2. Claire McGuinness, "What Faculty Think: Exploring the Barriers to Information Literacy Development in Undergraduate Education," Journal of Academic Librarianship 32, no. 6 (2006): 574.

3. Annmarie B. Singh, "A Report on Faculty Perceptions of Students' Information Literacy Competencies in Journalism and Mass Communication Programs: the ACEJMC Survey," College and Research Libraries 66, no. 4 (2005): 294-310.

4. Stuart Boon, Bill Johnston, and Sheila Webber, "A Phenomenographic Study of English Faculty's Conceptions of Information Literacy," Journal of Documentation 63, no. 2 (2007): 204-28.

5. Shelley Gullikson, "Faculty Perceptions of ACRL's Information Literacy Competency Standards for Higher Education," Journal of Academic Librarianship 32, no. 6 (2006): 583-92.

6. Christine Bruce, "Faculty-Librarian Partnerships in Australian Higher Education: Critical Dimensions," Reference Services Review 29, no. 2 (2001): 113.

7. Debbie Orr, Margaret Appleton, and Margie Wallin, "Information Literacy and Flexible Delivery: Creating a Conceptual Framework and Model," Journal of Academic Librarianship 27, no. 6 (2001): 457-63.

8. Christine Bruce, The Seven Faces of Information Literacy (Adelaide: Auslib Press, 1997).

9. Mary C. MacDonald, Andre J. Rathemacher, and Joanna M. Burkhardt, "Challenges in Building an Incremental, Multi-Year Information Literacy Plan," Reference Services Review 28, no. 3 (2000): 240-47.

10. Wenxian Zhang, "Building Partnerships in Liberal Arts Education Theory: Library Team Teaching," Reference Services Review 29, no. 2 (2001): 141-49.

11. Christine Bruce, Paul Chesterton, and Craig Grimison, "Constituting Collective Consciousness: Information Literacy in University Curricula," International Journal for Academic Development 7, no. 1 (2002): 31-40.

12. Fiona Salisbury and Jenny Ellis, "Online and Face-to-Face: Evaluating Methods for Teaching Information Literacy Skills to Undergraduate Arts Students," Library Review 52, no. 5 (2003): 209-17.

13. Zhijia Shen and Keith Gresham, “When Technology Transforms Research Methodology: The Role of Librarians in Reforming the Curriculum," Reference Services Review 28, no. 4 (2000): 360-68.

14. Irene Doskatsch, "Perceptions and Perplexities of the Faculty-Librarian Partnership: An Australian Perspective," Reference Services Review 31, no. 2 (2003): 111-21.

15. Bill Johnston and Sheila Webber, "Information Literacy in Higher Education: A Review and Case Study," Studies in Higher Education 28, no. 3 (2003): 345.

16. Ann M. Fiegen, Bennett Cherry, and Kathleen Watson, "Reflections on Collaboration: Learning Outcomes and Information Literacy Assessment in the Business Curriculum," Reference Services Review 30, no. 4 (2002): 307-18.

17. Jacqui Weetman, "Osmosis: Does It Work for the Development of Information Literacy?" Journal of Academic Librarianship 31, no. 5 (2005): 456-60.

18. McGuinness, "What Faculty Think."

19. Ibid., 577.

20. American Library Association, Presidential Committee on Information Literacy: Final Report (Chicago, Ill.: American Library Association, 1989). Available online at www.ala.org/ala/mgrps/ divs/acrl/publications/whitepapers/presidential.cfm. [Accessed 28 May 2009].

21. Chartered Institute of Information Professionals, Information Literacy: A Definition (London: CILIP, 2004). Available online at www.cilip.org.uk/policyadvocacy/learning/informationliteracy/ definition/default.htm. [Accessed 28 May 2009].

22. Society of College, National and University Libraries, Information Skills in Higher Education: A SCONUL Position Paper (London: SCONUL, 1999). Available online at www.sconul.ac.uk/ groups/information_literacy/papers/Seven_pillars2.pdf. [Accessed 28 May 2009].

23. Weetman, "Osmosis."

24. Ibid., 459.

25. The College of New Jersey, Liberal Learning Goals and Outcomes (2003). Available online at www.tcnj.edu/ liberal/outcomes.html. [Accessed 28 May 2009].

26. Gloria J. Leckie, "Desperately Seeking Citations: Uncovering Faculty Assumptions about the Undergraduate Research Process," Journal of Academic Librarianship 22, no. 3 (1996): 201-10.

27. Association of College and Research Libraries, Information Literacy Competency Standards for Higher Education (Chicago, Ill.: ACRL, 2000). Available online at www.ala.org/ala/mgrps/divs/ acrl/standards/standards.pdf. [Accessed 28 May 2009]. 
28. Gullikson, "Faculty Perceptions."

29. Weetman, "Osmosis," 457.

30. Gullikson, "Faculty Perceptions," 585.

31. Singh, "A Report on Faculty Perceptions," 296.

32. Weetman, "Osmosis," 458.

33. Jacqueline D. Weetman, The Management of Information Literacy at De Montfort University (MBA diss., University of Leicester, 2004).

34. For example, Johnston and Webber, "Information Literacy in Higher Education"; Barbara Valentine, "The Legitimate Effort in Research Papers: Student Commitment versus Faculty Expectations," Journal of Academic Librarianship 27, no. 2 (2001): 107-15.

35. Leckie, "Desperately Seeking Citations," 202.

36. Valentine. "The Legitimate Effort in Research Papers," 112.

37. Gullikson, "Faculty Perceptions."

38. Association of College and Research Libraries, Information Literacy Competency Standards.

39. Leckie, "Desperately Seeking Citations," 203.

40. Singh, "A Report on Faculty Perceptions."

41. Weetman, "Osmosis," 458.

42. Society of College, National and University Libraries, Information Skills in Higher Education.

43. Association of College and Research Libraries, Information Literacy Competency Standards.

44. Deborah V. Dolan and Georgina Martorella, "Discipline-Based Information Literacy and the Lifelong Learner," International Journal of Learning 10 (2003): 1317-32.

45. Society of College, National and University Libraries, Information Skills in Higher Education.

46. Association of College and Research Libraries, Information Literacy Competency Standards.

47. Gullikson, "Faculty Perceptions."

48. Anita Cannon, "Faculty Survey on Library Research Instruction," RQ 33, no. 4 (1994): 525.

49. Patricia Senn Breivik, Student Learning in the Information Age (Phoenix, Ariz.: Oryx Press, 1998).

50. Jacqui Weetman DaCosta, "How Passion and Perseverance Steered the Course Towards a University's Information Literacy Framework," in Uncharted Waters: Tapping the Depths of our Community to Enhance Learning: Thirty-Fifth National LOEX Library Instruction Conference Proceedings, San Diego (CA), May 3-5, 2007 (Ypsilanti, Mich.: Eastern Michigan University), 2009.

51. McGuinness, “What Faculty Think," 580. 